\title{
ECONOMIC DEVELOPMENT UNDER REFORM AND WORLD INTEGRATION \\ AND THE MAIN FACTORS INFLUENCING THE ECONOMIC GROWTH IN \\ VIETNAM
}

\author{
Nguyen Thi Canh, Tran Hung Son \\ University of Economics and Law, VNU-HCM \\ (Manuscript Received on October 04 ${ }^{\text {th }}, 2010$, Manuscript Revised April 21 ${ }^{\text {st }}, 2011$ )
}

\begin{abstract}
The purpose of this paper was to give an overview of economic development under reform and world integration and to evaluate the main factors influencing the growth of the Vietnamese economy during the reform period (1990-2009). Based on statistical data on the Vietnamese economy in the period of 1990-2009, this study analyzed the factors affecting economic growth. The policy changes, economic development, poverty rates and living standards of Vietnamese population are analyzed over the reform period using qualitative methods. The results of this study show that economic growth under reform and world integration has reduced the poverty rate and increased living standards of population in Vietnam. An evaluation of the factors influencing economic growth is made using a quantitative model of total factor productivity (TFP) and another econometric model. The findings from this quantitative analysis show that the growth of the Vietnamese economy was determined by two factors: (1) capital investments, including foreign direct investment (FDI) and (2) the growth of exports. The results of these qualitative and quantitative analyses lay the foundation for policy recommendations for Vietnam Government to develop economy in the future
\end{abstract}

Keywords: Factors, Reform, Economic Growth, Poverty, Private Ownership, Land Rights, Membership in International Organizations, Capital and Foreign Investment, Imports and Exports, An Empirical Model, Total factor productivity (TFP), Cobb-Douglas function.

\section{AN OVERVIEW OF ECONOMIC REFORM AND TRANSFORMATION PROCESS IN VIETNAM}

After the sixth congress of Vietnam Communist Party in 1986, Vietnamese economic policy underwent a complete change. The new economic policy changed from a command, planned economy to a free-market, multisectored one. This period of change and new economic policies is called the renovation process ("Doi moi" in Vietnamese), and refers to the transition from a command-planned economy to the current, free-market one. In this process Vietnamese Government had to create:

$\checkmark$ A new legal system;

口 Macro-Economic Policies;

$\square$ Restructuring the state owned enterprises;

口 Developing the private sector;

$\checkmark$ Administrative reform; 
$\square$ Preparing the conditions to go into integration process...

The Law on Foreign Investment was promulgated by the Vietnam National Assembly on December 29, 1987, and amended firstly in June 1990, secondly in December 1992 and finally in 1996. It is a legal document stipulating the basic principles concerning direct investments of foreign investors in Vietnam. According to this law, foreign investors can invest in Vietnam in any of the following forms:

- Contract of business cooperation

- Joint-ventures

- $100 \%$ foreign invested enterprise

\section{Private Ownership}

Since 1988, the Vietnamese government encouraged private enterprises, and this encouragement became official policy when the Private Business and Company Laws were established in 1990. In the private sector, the implementation of regulations provides the basis for private business to develop "without limitation in terms of scope and type in sectors and occupations that are not forbidden by laws." Private enterprise, limited liability companies, and joint-stock companies, all of which are medium- and small-sized companies operate under these Private Business and Company Laws.

In the private sector, the simplest form of business organization is a business owned by an individual. The second form is a business owned by groups of individuals, which can be called a partnership or collective business.
Sole proprietorship and partnership business are useful in helping individuals of limited means to start a business without much property (money). In Vietnam, both such businesses are very small, with usually less than 25 million VND of capital and less than 20 employees. By American standards, these might be called "micro-enterprises." They are formed and operated by Prime Minister Decision No.66 under the Laws.

The Law on Foreign Investment (promulgated by the SRV National Assembly on December 29, 1987, amended first time in June 1990, second time in December 1992, and third time in 1996, and last time in 2000) is a legal document stipulating the basic principles concerning direct investment of foreign investors in Vietnam. According to the Law on Foreign Investment, foreign investors can invest in Vietnam by the following forms:

- Contract of business cooperation;

- Joint-venture;

- $100 \%$ foreign invested enterprise;

- Enterprise in Export Processing Zone (EPZ); and

- Build-Operate-Transfer (BOT) project.

Since 1992, the Vietnamese Government began projects for converting state owned enterprises (SOEs), including the privatization, incorporation, or liquidation of a number of SOEs. This program is a part of the government's overall program to shift the Vietnamese economy from a command system to a free-market system. The Law on State Enterprises issued in April 1995 sharply

\section{Trang 6}


distinguishes between enterprises with public service functions and those operating on a commercial basis in a market economy. It also provides the legal framework for establishing state corporations. Today, we can see the initial results from the implementation of such pilot corporatization and equalization, which establish the institution and create the other necessary conditions for this work's execution on a large scale.

Since 2005, all kinds of business organizations in Vietnam (State Owned Enterprise, Private Domestic Company and foreign companies) are operating under one law-Business Law. With this new law, the Vietnamese Government created equality among different economic entities.

The transformation process has changed the ownership, management style, income distribution, and the role of Government in Vietnam's economy. In its former command economy, ownership was based only on State and cooperative. Now, it is based on the multisectored economy of state, cooperatives, private ownership, and foreign ownership. In the past the economy was closed, the Government had control of everything (e.g., establishing the prices of goods; the salaries paid to workers; production and trading decisions, subsidized capital from budget, etc. Today, like the U.S., the Government manages the economy by laws; the prices of goods are established by market forces; entrepreneurship is encouraged; trade is slowly being liberalized; the economy is open to world markets; the real estate market is open and financial and labor markets have been established.

In Vietnam there are now seven kinds of business organizations: state-owned, cooperative, private, limited, join-stock, foreign companies and small family business. All these are operating under laws. With these new policies, the government gives state enterprises autonomy and establishing market relations; implementing the state owned enterprises reform program, including the privatization, incorporation, or liquidation of a number of SOEs; establishing Private Business and Company Laws ( now combined into Business Law and Investment Law); attracting foreign investment by establishing a new industrial zone, infrastructure fund and 'exchanging land by infrastructure'; reducing administrative formalities; and creating new programs to eradicate hunger and poverty.

\section{Land Rights}

State polices gave autonomy to farm and household business to make their own production and consumption decisions. Combined with polices transferring long-term rights to use land to each farm and household, these have had a positive impact on living and production standards. As a result, for example, agriculture productivity has increased and the living standards of farmers have improved. They have also promoted a renovation of the operations of agricultural co-operatives and the development of new types of co-operatives. Since 1993, a new law on land was established, enabling Vietnamese people to buy and can sell 
their land use rights (land continues to be owned by the federal government, people only own land use right, and before Vietnamese people couldn't buy or sell a land).

Membership in International Organizations

After 20 years of interruption, Vietnam resumed its relationship with such multilateral credit organizations as the International Monetary Fund (IMF), the World Bank (WB), and the Asian Development Bank (ADB) in October 1993. Consequently, Vietnam applied for membership in the Association of SouthEast Asian Nations (ASEAN) and became an official member in July 28, 1995. As an ASEAN member, Vietnam is committed to implement Common Effective Preferential Tariff Scheme (CEPT) for the realization of the ASEAN Free Trade Area (AFTA).

Vietnam applied for membership in the World Trade Organization (WTO) in January 1995 and became a full WTO member in the end of 2006. Vietnam has also been an official member of Asia - Europe Meeting (ASEM) since 1996 and member of Asia Pacific Economic Corporation (APEC) since 1998.
Although the ASEM and APEC commitments and obligations are not binding, they all conform to WTO principles and thus, more or less, pressure Vietnam to make economic reforms. As a result of these associations, Vietnam now maintains trade links with 178 countries and territories, including all the world powers. Vietnam has also signed a bilateral trade agreement with 81 countries, of which the Vietnam-U.S. bilateral trade agreement (BTA) is the most comprehensive. It was negotiated on the basis of WTO principles and standards.

Table 1 provides a summary of Vietnam's transformation process and Table 2 shows the major policy changes and integration times.

Table 1. The Vietnamese Transformation Process

\begin{tabular}{|l|l|l|}
\hline \multicolumn{1}{|c|}{ Specific style } & The command, planned economy & Transitional economy to the market \\
\hline Ownership based on & State and Cooperative & $\begin{array}{l}\text { Multi-sectored economy (State, Cooperate, } \\
\text { Private, and Foreign) }\end{array}$ \\
\hline Legal environment & According to the some Regulations & According to the Laws and Regulations \\
\hline $\begin{array}{l}\text { Mechanism to establish a } \\
\text { price of goods }\end{array}$ & $\begin{array}{l}\text { Price of goods was established by } \\
\text { Government }\end{array}$ & Price of goods is established by Market \\
\hline Mechanism of management & $\begin{array}{l}\text { Command, subsidies from budget, } \\
\text { closing economy }\end{array}$ & $\begin{array}{l}\text { Operating by supply-demand Law, free to make } \\
\text { business, liberalization of trade, open economy }\end{array}$ \\
\hline
\end{tabular}

\section{Trang 8}




\begin{tabular}{|l|l|l|}
\hline Distribution of the income & By contribution of the labor & $\begin{array}{l}\text { By contribution of the labor, investment capital, } \\
\text { and result of business/activities }\end{array}$ \\
\hline
\end{tabular}

Table 2. Major changes in economic policies since the beginning of the reform era in Vietnam and important integration time

\begin{tabular}{|l|l|}
\hline Year & Changes in economic policies \\
\hline 1986 & Party Congress declares beginning of doi moi (Reform) \\
\hline 1987 & Law on foreign direct investment - introduction of 'open door' policy \\
\hline 1988 & Encouragement of private enterprises becomes official policy \\
\hline 1989 & $\begin{array}{l}\text { Foreign exchange rate system unified } \\
\text { All budgetary export subsidies removed }\end{array}$ \\
\hline 1990 & Private, Limited and Joint-Stock Company Laws allowed private company operating in Vietnam \\
\hline 1992 & Private companies allowed to directly engage in international trade \\
\hline 1993 & state owned enterprises (SOEs), including privatization, corporatization and liquidation of a number of SOEs \\
\hline 1994 & Vietnam gains GATT observer status \\
\hline 1995 & Vietnam joins ASEAN \\
\hline 1998 & A member of Asia Pacific Economic Corporation (APEC) \\
\hline 2005 & Business Law allowed the same policy for all kinds of business by ownership \\
\hline 2006 & Vietnam joins WTO \\
\hline
\end{tabular}

\section{ECONOMIC DEVELOPMENT UNDER ECONOMIC REFORM AND WORLD INTEGRATION OVER 20 YEARS IN VIETNAM}

Economic reform in Vietnam means transforming public sector and developing private sector and free-market. One way to measure this transformation process is to examine the ownership of both large and small business enterprises (Table 3). The number of SOEs has decreased about $75 \%$ in the transition period, from more than 15,000 units at the end 1991 to around 3,700 now. In contrast, business organizations in the private sector have increased from 26,091 companies (accounting for about $78 \%$ of total number companies in 1995) to 123,392 companies in 2006 (accounting for about $93.96 \%$ of total companies). Similarly, foreign directinvestment projects have increased from more than 1,000 companies in 1995 to 4,220 now. Starting with a few thousand household businesses at the beginning period of renovation process, there are now hundreds of thousands of non-agricultural productive household businesses and micro-enterprises. 
Table 3. Number of Enterprises by Ownership Sector

\begin{tabular}{|c|c|c|c|c|c|c|c|c|}
\hline$\overbrace{\text { Ownership }}^{\text {Years }}$ & 1995 & 2000 & 2001 & 2002 & 2003 & 2004 & 2005 & 2006 \\
\hline Totals & 33,448 & 42,288 & 51,680 & 62,908 & 72,012 & 91,755 & 112,952 & 131,318 \\
\hline Number of SOEs & 6,310 & 5,759 & 5,355 & 5,363 & 4,845 & 4,596 & 4,086 & 3,706 \\
\hline$\%$ of SOEs & 18.87 & 13.62 & 10.36 & 8.52 & 6.73 & 5.01 & 3.62 & 2.82 \\
\hline $\begin{array}{l}\text { Numbers of } \\
\text { Domestic Private } \\
\text { companies }\end{array}$ & 26,091 & 35,004 & 44,314 & 55,237 & 64,526 & 84,003 & 105,169 & 123,392 \\
\hline $\begin{array}{l}\% \text { of Domestic } \\
\text { Private Companies }\end{array}$ & 78.00 & 82.77 & 85.75 & 87.81 & 89.60 & 91.55 & 93.11 & 93.96 \\
\hline $\begin{array}{l}\text { Number of FDI } \\
\text { Companies }\end{array}$ & 1,047 & 1,525 & 2,011 & 2,308 & 2,641 & 3,156 & 3,697 & 4,220 \\
\hline $\begin{array}{l}\% \text { of FDI } \\
\text { Companies }\end{array}$ & 3.13 & 3.61 & 3.89 & 3.67 & 3.67 & 3.44 & 3.27 & 3.22 \\
\hline $\begin{array}{l}\text { Small } \\
\text { establishments, } \\
\text { households }\end{array}$ & 612,977 & NA & NA & $2,619,341$ & $\begin{array}{c}2,712,17 \\
7\end{array}$ & $2,913,907$ & $3,053,011$ & $3,748,138$ \\
\hline
\end{tabular}

Source: Vietnam Government Statistic Office (GSO) 1995, 2000-2007

A second way to measure the impact of this transformation process is to measure Vietnam's gross domestic product (Chart 1). Economic reform and the transition to a market economy have led to strong economic growth. The Vietnamese economy has enjoyed growth and stability for more than 20 years during this time of transition. For example, gross domestic product (GDP) of Vietnam was only growing by $2.44 \%$ in 1985 before reform, but this has now increased to $4.45 \%$ per year in the period at the beginning of renovation (1986-1990), and has enjoyed an average growth rate of $7.44 \%$ per year in the period from 1991 to 2009. GDP per capita also has also increased after economic reform (from 105 USD in 1990 to 1,109USD in 2009)—see Chart 1 below. Similarly, the industrial and construction sector has achieved a high and stable growth rate, averaging $11.3 \%$ per year in the period 19902009. The average growth rate of the service sector was $7.16 \%$ per year and the average growth rate of agriculture sector was $4.2 \%$ per year during 1990 to 2009 (see Appendix 2).

As result of these forces, the economic structure of Vietnam is shifting from an agrarian society to a modern, industrialized economy. For example, (1) the share of the industrial and construction sector was $22 \%$ of the GDP in 1985 and this has increased to about $41 \%$ in 2009 , (2) the share of the service sector was $32 \%$ in 1985 , and has increased to $38 \%$ in 2009, and (3) the share of agriculture is down from $45 \%$ in 1985 to $21 \%$ in 2009 (see Chart 2 below). This shift of economic activity from an agriculture economy to manufacturing and service highlights Vietnam promise for the future.

\section{Trang 10}


Economic reform also changed the ownership structure of the Vietnamese economy. In 1985, before economic reform, there were only three sectors: state, cooperative, and individual household. There was no private or foreign sector. Since changing policy in 1988, Vietnam's 1990 share of domestic private sector (domestic private, limited companies) and share of foreign sector in GDP have been increasing (Chart 3). At the same time, the total share of state and cooperative sector have been decreasing in the transition period
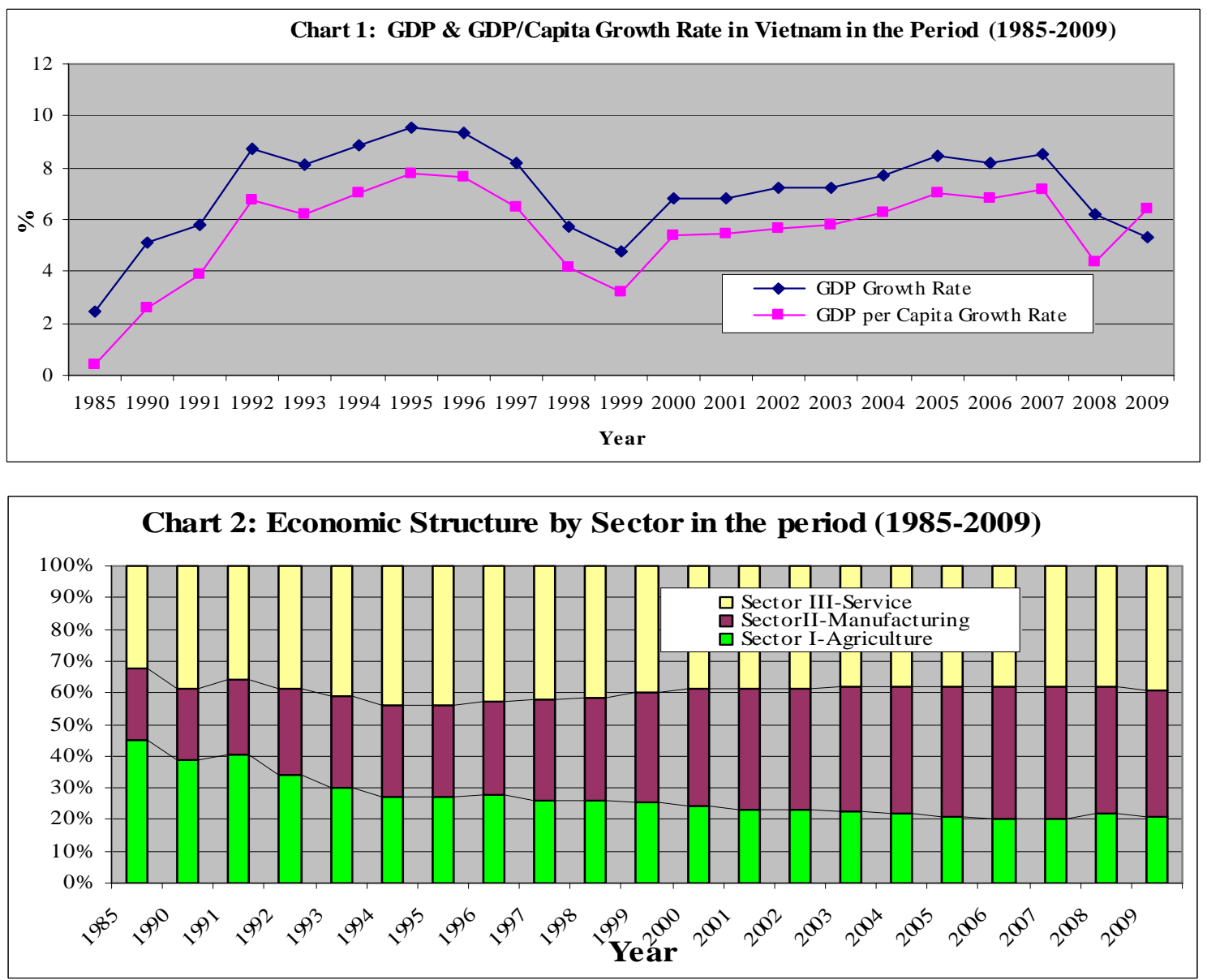

Besides economic reform, "reducing poverty" has been a priority for the Vietnamese Government. There are two programs in the government's Comprehensive Poverty Reduction and Growth Strategy to reduce poverty. The first, the Vietnamese Hunger Eradication and Poverty Reduction Program
(Program 133), was launched in 1996 to integrate a range of anti-poverty initiatives that target 11 specific areas including health, education, and credit for the poor. In 1998, Program 135 was established to provide basic services to poor communities in mountainous and remote areas. 


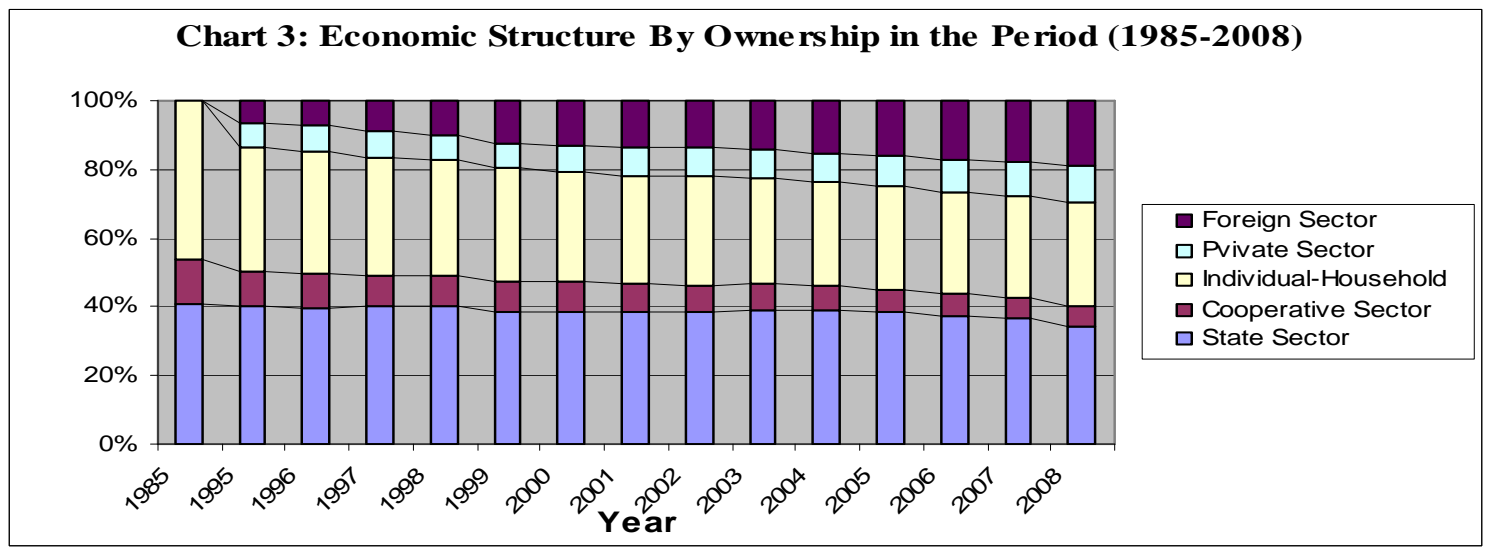

Economic development and povertyreduction programs have had a positive impact on the living standards of the population. for example, there are now a million new jobs created every year, living standards now are more stable, and these standards are gradually improving. average income-gdp per capita per year has increased about 10 times, from less than 40 us dollars per capita in 1985, to about 105 us dollars per capita in 1990, and to about 1,047 us dollars per capita in 2008 (see chart 4 below).

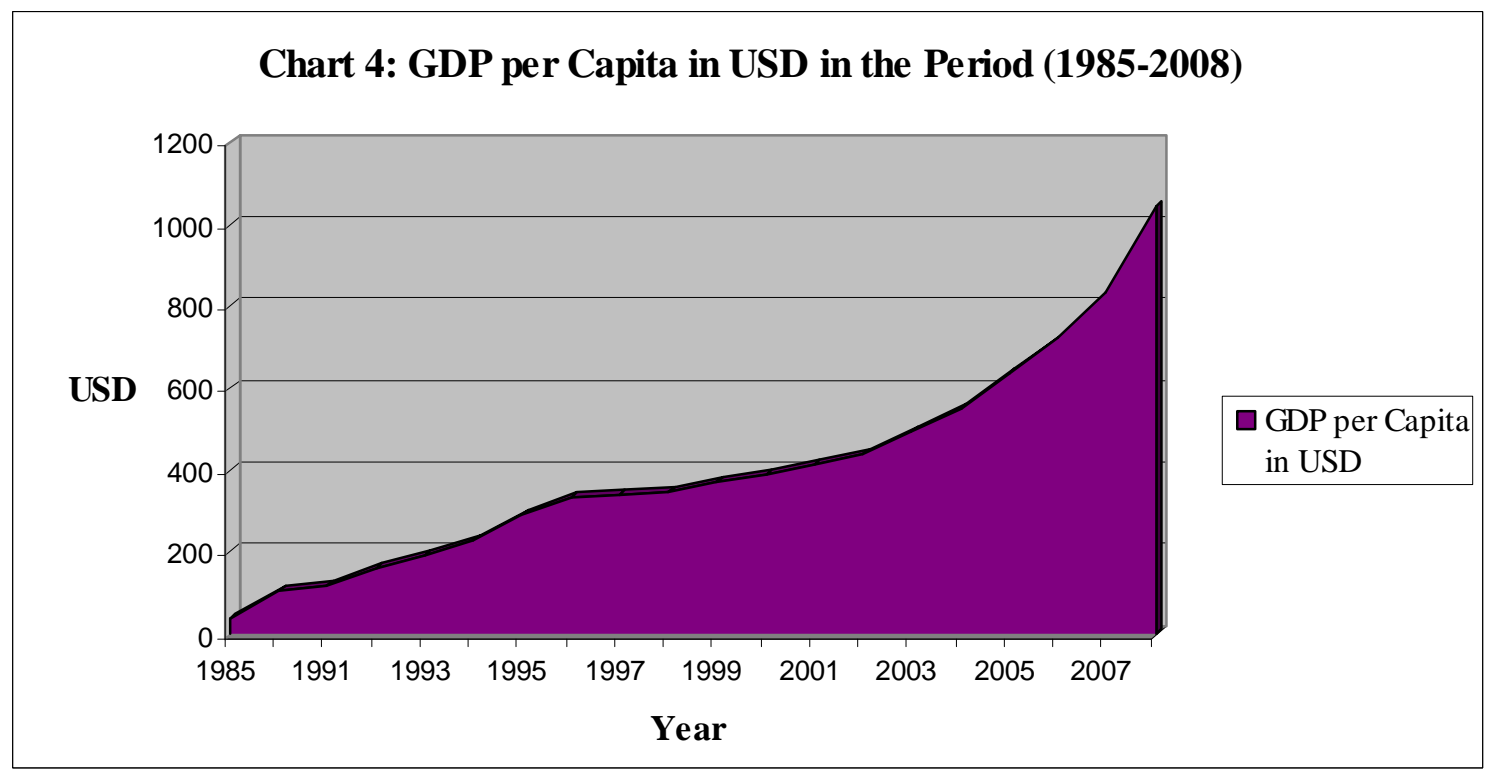

The World bank uses gross national income per capita (GNI) to classify national economies into one of four income groups: The low-income group includes countries having GNI or GDP per capita, of 935 US dollars or less. The lower-middle income group includes countries with GNI or GDP per capita from 936 US dollars to $\$ 3,705$. The upper-middle income group includes countries having GNI or GDP per capita from $\$ 3,706$ to $\$ 11,455$. The high-income group includes countries with GNI or GDP per capita is $\$ 11,456$ or more.

\section{Trang 12}


With GDP per capita of 1,047 US dollars, 2008 was the first year that Vietnam got out of the low-income country group and joined those countries in the lower-middle group.

The vietnamese general statistics office uses two measures of poverty: (1) the general poverty line and (2) the food poverty line. the food poverty line is calculated according to the expenditure required to purchase 2100 calories of food per person per day. the general poverty line is calculated on the basis of a "basket of goods essential for well-being", combined with expenditures sufficient to meet the standard of the food poverty line.
In 1993 the food poverty line was 62,477 VND per person-month, and the general poverty line was 96,700 vnd per person-month. in 1998 , the food poverty line was 107.236 vnd per person-month and general poverty line was 149,156 VND per person-month. according to the results of the government's living standards surveys, the poverty rate of the population by general poverty line has been reduced from $58.1 \%$ in 1993 to $37.4 \%$ in $1998,28.9 \%$ in 2002 , and $16 \%$ in 2007 . the poverty rate using the food poverty line has been reduced from $24.9 \%$ in 1993 to $15 \%$ in $1998,10.9 \%$ in 2002 and $4.9 \%$ in 2007 (see chart 5 bellow).

Chart 5. The vietnamese poverty rates, 1993 to 2007

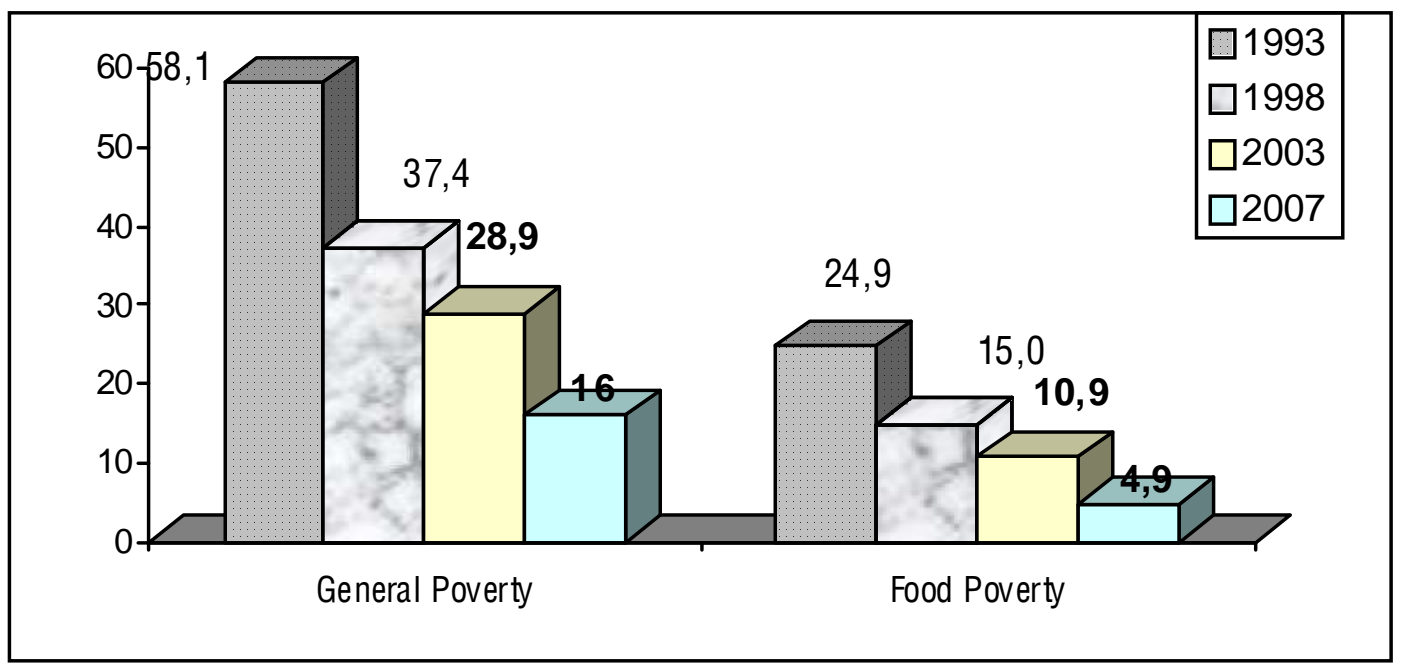

\section{THE MAIN FACTORS INFLUENCING}

\section{THE ECONOMIC GROWTH}

\section{Capital and Foreign Investment}

Economic growth has been high in Vietnam over the last 20 years due to several major factors. One is investment capital, which has been increasing from different sources and is concentrated in developing specific economic industries. Another is social investment outlays, which have increased about 28.5 times in the last 18 years from 7,581 billions VND at current price (\$USD 1.35 billions) in 1990, 72,447 billions VND (\$USD 6.9 billions) in 1995 to 637,300 billions VND (about \$USD 38.6 billions) in 2008 . 
Investment capital has increased strongly as the Vietnamese economy has opened its economy to the world during its integration process. As result, foreign direct investment (FDI) has been increasing (see Chart 6). The foreign investment law was issued in 1987 and since 1988 foreign companies have established in Vietnam. There are 12,206 foreign investment projects licensed in the period of 1988-2009, accounting for 192.8 US\$ billions of the total registered capital, including 67.4 US\$ billions of implementation capital.

Foreign investment projects have been increasing year by year from different countries, including some from developing countries. The main countries with large foreign investment projects are the Asian Countries-e.g., Taiwan, Hong Kong, Korea, Japan, Singapore and Thailand. The developed countries with the most foreign projects and investments are France and United States. Chart 7 shows that, with integration policy, the investment capital source has been changing by ownership. Investment capital share of state sector was $40.2 \%$ of total investment capital in 1990 has decreased to $28.9 \%$ in 2008 ; investment capital share of non-state invested (domestic private sector) was $46.7 \%$ of total investment capital in 1990 and has decreased to $29.39 \%$ in 1995 but is now up again to $41.3 \%$ in 2008. In the meantime the investment capital share of foreign sector (FDI) was $13.1 \%$ of total investment capital in 1990 has increased in $29.8 \%$ in 2008. Increase in FDI has been speeding up export and import strongly in past years (see Chart 6 below)

\section{Imports and Exports}

Vietnam's integration policy also impacted Vietnamese exports and imports. Chart 8 shows that the value of exports has grown at an average annual rate of $19.9 \%$ per year during last 18 years (1990-2008). During the same period, the value of imports has grown at an average rate of $20.62 \%$ per year. The main products for export are petroleum, crude, rice, coffee, rubber, shoes and sandals, textiles, sewing products, vegetables and fruit, and marine products.

The main import goods are machines, oils and some industrial inputs, and high-quality consumption goods. In 1990, the state's sector played a leading role in exportation and importation but its role has decreased steadily in the past 10 years. Export value structure of the domestic sector was down from $70.73 \%$ in 1990 to $42.8 \%$ in 2008 and import value structure was down from $82.0 \%$ in 1990 to $63.3 \%$ in 2008. The foreign sector of the economy plays an important role in the export and import in last few years. For example the share of foreign sector accounted for $57.2 \%$ of export value and $36.7 \%$ import value in 2008 (see chart 8).

\section{Trang 14}



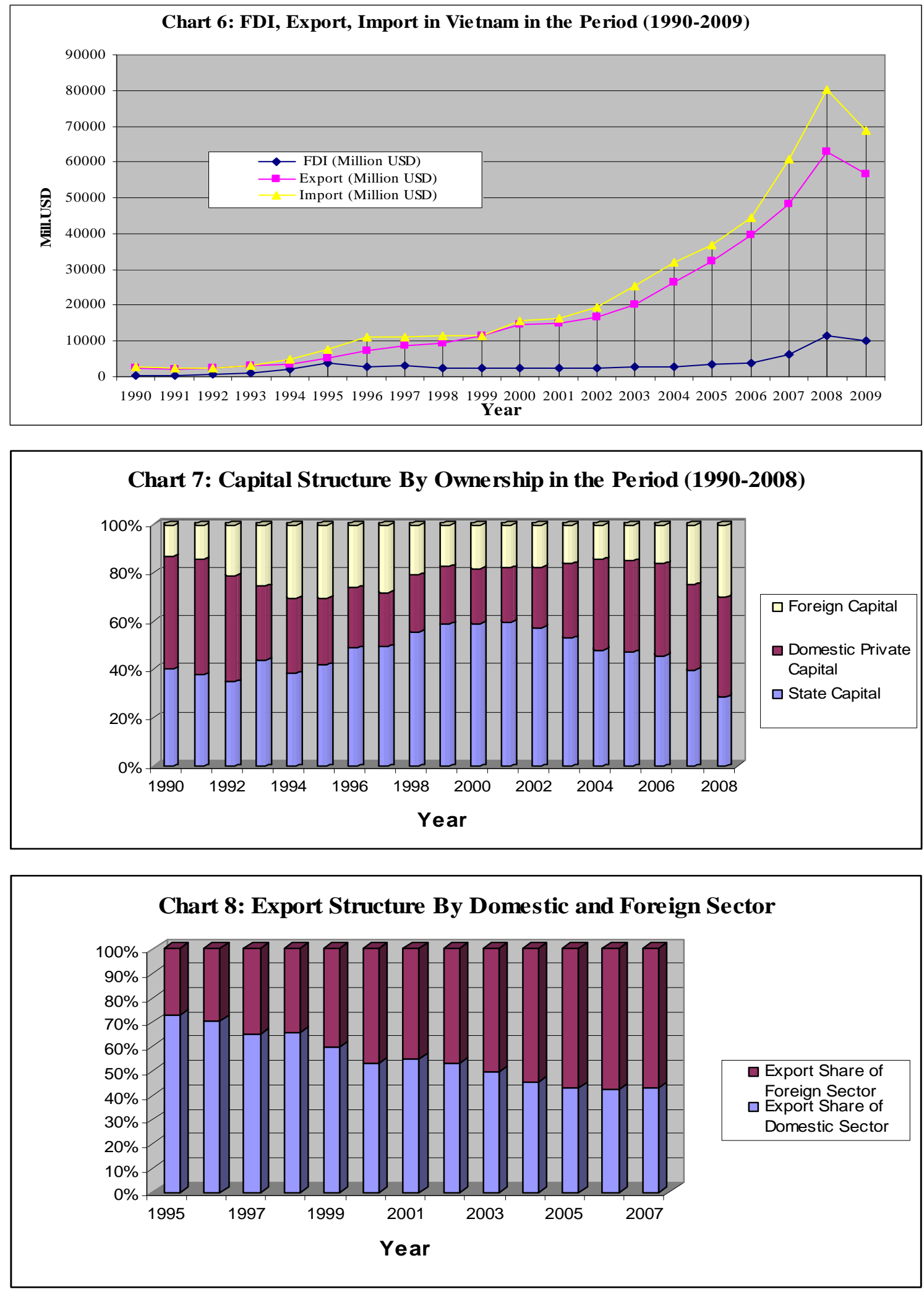

Trang 15 
The relationship between export and GDP growth can be analyzed to determine the

Export contributes in $1 \%$

economic growth

$$
=\frac{\text { Export Growth Rate }(\%)}{\text { GDP Growth Rate }(\%)} \times \frac{\text { Export }}{\text { GDP }}
$$

Based on the above formula, the author calculated the contribution of export to $1 \%$ economic growth in Vietnam last years is about of $24 \%$.

\section{An Empirical Models}

The author analyzed the relationship between capital and economic growth using the Cobb-Douglas production function: $\mathrm{Y}=$ $\mathrm{AK}^{\alpha} \mathrm{L}^{\beta}$,

Where $\mathrm{Y}$ is output (GDP), $\mathrm{K}$ is capital, $\mathrm{L}$ is labor and A is "knowledge" or the "effectiveness of labor" or total factor productivity (TFP) [2, p 7] and [1, p. 7, 8...]. influence of export to economic growth using the following formula:
The data sources used to calculate these indicators and this econometric model (CobbDouglas function) are based on statistic data (GDP, capital and labor for whole economy and for 3 sectors from 1990 to 2007)

The translog Cobb-Douglas production function is given by:

$$
\log Y=\log A+\beta_{K} \log K+\beta_{L} \log L\left(\alpha=\beta_{K},\right.
$$
$\left.\beta=\beta_{L}\right)$.

The outputs from this model using SPSS program may be found in Appendix 4. Table 4 shows the results of this model with $\alpha=\beta_{K}$, and $\beta=\beta_{L}$.

\begin{tabular}{|c|c|c|c|c|c|c|}
\hline \multicolumn{2}{|c|}{ Model } & \multicolumn{2}{|c|}{ Unstandardized Coefficients } & \multirow{2}{*}{$\begin{array}{l}\text { Standardized } \\
\text { Coefficients }\end{array}$} & \multirow{2}{*}{$\mathrm{t}$} & \multirow{2}{*}{$\begin{array}{l}\text { Significance } \\
\text { Std. Error }\end{array}$} \\
\hline & & B & Std. Error & & & \\
\hline \multirow[t]{3}{*}{1} & (Constant) & 1.566 & .094 & & 16.585 & .000 \\
\hline & $\log K$ & .546 & .015 & .870 & 35.223 & .000 \\
\hline & $\log \mathrm{L}$ & .235 & .019 & .304 & 12.330 & .000 \\
\hline
\end{tabular}

Table 4.Model Result-Coefficients (a)

a Dependent Variable: LogGDP

From above result we have the following estimates: $\mathbf{G D P}=\mathbf{1 . 5 6 6} \mathrm{K}^{\mathbf{0 . 8 7}} \mathrm{L}^{\mathbf{0 . 3 0 4}}$

and from Total Factor Productivity Model we know $\boldsymbol{G}_{\boldsymbol{G D P}}=\boldsymbol{G}_{\boldsymbol{A}}+\boldsymbol{\beta}_{\boldsymbol{K}} \boldsymbol{G}_{\boldsymbol{K}}+\boldsymbol{\beta}_{\boldsymbol{L}} \boldsymbol{G}_{\boldsymbol{L}}$, [3, p. 38]

where $G_{G D P}$ is GDP growth rate, $G_{A}$ is contribution of total factor productivity to economic growth; $G_{K}$ is capital $(\mathrm{K})$ growth rate, $\beta_{K}$ is regression coefficient of capital $(\mathrm{K})$;
$G_{L}$ is growth rate of labor and $\beta_{L}$ is the regression coefficient of labor (L).

The capital growth rate is defined by calculating the average growth rate of capital investment and subtracting the depreciation rate. The depreciation rate in Vietnam ranges from $10 \%$ to $30 \%$ for machinery, and ranges from $2 \%-3 \%$ for buildings. A reasonable

\section{Trang 16}


average is $8 \%$ (to define this $8 \%$ is based on weight and depreciation rate of each group fixed asset). Capital investment growth rate in the past 20 year is about $14.17 \%$ per year. So $G_{K}$ in the model TFP (Total Factor Productivity) is Capital Growth Rate Depreciation Rate $=14.17 \%-8 \%=6.17 \%$

The growth of GDP in Vietnam for the period 1990 to 2007 is $7.64 \%$. From the results of the regression model we have $\beta_{K}=0.87$, which means that the contribution of Capital Factor to the economic growth is $6.17 \% \times 0.87=$ $5.38 \%$. Average growth rate of labor in the period (1990-2007) in Vietnam is $2.63 \%, \beta_{L}$ from regression model is 0.304 , so contribution of labor factor to the economic growth is $0.304 \times 2.63 \%=0.8 \%$, the rest is contribution of total factor productivity (technology, management changing) is $7.64 \%-(5.38 \%+$ $0.8 \%)=1.46 \%$. Thus, relatively, "capital" contributed about $70.42 \%(5.38 / 7.64)$ to economic growth in Vietnam in the past 20 years, "labor" contributed about $10.47 \%$ $(0.8 / 7.64)$, and "total factor productivity" contributed about $19.11 \%(1.46 / 7.64)$ to economic growth in Vietnam in past two decades.

The results of regression equations indicate that capital plays an important role of economic growth of Vietnam. As mentioned above, the reform process has resulted in attracting significant foreign capital inflows into Vietnam. The foreign capital inflow is about $30 \%$ of total capital in Vietnam. Foreign capital inflows into Vietnam include FDI, ODA,
Oversea national currency exchange and FII. These capital investments are important factor for the growth of the Vietnam's economy. The regression equations of the relation between FDI and growth show that FDI Foreign direct investment (FDI) has contributed to impressive economic growth in Vietnam

Based on the existing literature, it can be argued that economic growth and FDI depend

on a number of factors. Some of the main determinants are discussed below. The discussion is used to develop an empirical model.

\section{Determinants of economic growth}

\section{Human capital}

Human capital is long regarded as a determinant of economic growth (Mankiw (1992), Barro and Sala-i-Martin (2004), and Benhabib and Spiegel (1994)). Human capital also affects growth through its interaction with FDI. A number of proxies have been used to measure human capital. This study uses the number of university and college enrolment per thousand persons as a proxy for human capital in Vietnam.

Exports

The endogenous growth theory pioneered by Romer (1986) and Lucas (1988) has provided persuasive evidence for the proposition that an increase in exports as a percentage of GDP has a positive effect on economic growth. Grossman and Helpman (1991) and Barro and Sala-i-Martin (2004) have argued that a more open trade regime leads to a greater ability to absorb 
technological progress and export goods that stimulates economic growth. Grossman and Helpman (1991) and Rodrik (1992) have pointed out that exports can potentially create growth-accelerating forces.

\section{Government Consumption}

Government Consumption has a significant positive impact on economic growth, because this consumption can create more social capital and then has positive impact on economic growth. Blankenau and Simpson (2004), Glomm and Ravikumar (1992, 1997, 1998), Eckstein and Zilcha (1994), Kaganovich and Zilcha (1999), Cassou and Lansing (2001) and Blankeanu (2003) have suggested that Government Consumption are positively related to economic growth in long-term. This study uses the annual government consumption as a percentage of GDP as a measure of government consumption in Vietnam.

\section{Other determinants}

The other well-known determinants of economic growth are domestic investment, labor force growth rate and FDI, both of which have been included as determinants of economic growth in Vietnam.

Based on the existing literature, the linkage between FDI and GDP growth in Vietnam is empirically examined by making use of the following equation.

GDP = f (FDI; DI ; HC; EX; GC; LA; FDI*HC ; FDI*EX)

Based on theoretical and empirical research on the impact of FDI on economic growth, a system of equation is formed in which the real economic growth rate (GDP) are determined by FDI inflow (FDI), domestic investment (M), human capital (HC), level of export (EX), government consumption (GC), growth rate of labor force (LA), interaction of FDI and human capital (FDI*HC) to show the role human capital in the contribution of FDI to economic growth, interaction of FDI and export $\left(\mathrm{FDI}^{*} \mathrm{EX}\right)$ to show the role FDI in the contribution of export to economic growth.

Table 5. Variable definitions

\begin{tabular}{|c|l|}
\hline Abbreviations & \multicolumn{1}{|c|}{ Variable definition } \\
\hline GDP & economic growth rate (annual \%) \\
\hline FDI & The ratio of realized FDI to GDP \\
\hline DI & $\begin{array}{l}\text { The ratio of realized domestic } \\
\text { investment to GDP }\end{array}$ \\
\hline HC & $\begin{array}{l}\text { Number of university and college } \\
\text { students }\end{array}$ \\
\hline EX & Ratio of exports to GDP \\
\hline GC & $\begin{array}{l}\text { The ratio of government consumption to } \\
\text { GDP }\end{array}$ \\
\hline LA & Growth rate of labor force \\
\hline
\end{tabular}

The results of the regression models are presented in Table 6 . Table 6 suggests that FDI is an important determinant of economic growth in Vietnam. The estimated coefficient of FDI in Table 6 is significant at 5\% level. In other words, one can argue with $95 \%$ confidence that increase in FDI in Vietnam increases economic growth. Specifically, it is possible to argue that, other things remaining constant, an increase $1 \%$ in the ratio of realized FDI to GDP in Vietnam would contribute to an approximate $0.55 \%$ increase in economic growth.

\section{Trang 18}


The estimated coefficient of DI in Table 6 is significant at $1 \%$ level, implying that an increase $1 \%$ in the ratio of realized DI to GDP in Vietnam would contribute to an approximate $3 \%$ increase in economic growth.

The estimated coefficient of EX is significant at $5 \%$ level. It is possible to argue that, other things remaining constant, an increase $1 \%$ in the ratio of export to GDP in Vietnam would contribute to an approximate $0.168 \%$ increase in economic growth.

Human capital has a positive and statistically significant impact on economic growth in Vietnam, but the effect is poor. This result can be explained that the quality of human capital in Vietnam is poor. Therefore it is necessary to improve the education to increase the quality of human capital in the future.

The interaction of export and FDI has a positive and statistically significant impact on economic growth in Vietnam. Once again, the result indicates the important role of FDI in export of Vietnam.

The interaction of FDI and human capital has a positive and statistically significant impact on economic growth in Vietnam, but the effect is poor. This result can be explained that the quality of Vietnamese labor force is low and this constraints the benefitting from knowledge spillovers from FDI.

The estimated coefficient of government consumption and growth rate of labor force is not statistically significant.

Table 6. Estimated results for Equation (5)

\begin{tabular}{|c|c|c|c|c|}
\hline \multicolumn{3}{|c|}{ Dependent Variable: GDP } & & \\
\hline \multicolumn{3}{|c|}{ Method: Least Squares } & & \\
\hline \multicolumn{3}{|c|}{ Sample: 19902008} & & \\
\hline \multicolumn{3}{|c|}{ Included observations: 19} & & \\
\hline Variable & Coefficient & Std. Error & t-Statistic & Prob. \\
\hline $\mathrm{C}$ & 6.894207 & 1.522252 & 4.528952 & $0.0019^{*}$ \\
\hline FDI & 0.553473 & 0.178399 & 3.102451 & $0.0146^{* *}$ \\
\hline DI & 2.994175 & 0.873248 & 3.428779 & $0.009^{*}$ \\
\hline EX & 0.16863 & 0.063839 & 2.641506 & $0.0296^{* *}$ \\
\hline $\mathrm{HC}$ & 0.00701 & 0.003236 & 2.16727 & $0.0621^{* * * *}$ \\
\hline LA & 0.05142 & 0.116796 & 0.440252 & 0.6714 \\
\hline GC & -0.00096 & 0.011369 & -0.08404 & 0.9351 \\
\hline EX*FDI & 0.20462 & 0.084209 & 2.42984 & $0.0412^{* *}$ \\
\hline FDI*HC & 0.000903 & 0.000413 & 2.184802 & $0.0604^{* *}$ \\
\hline R-squared & 0.99816 & \multicolumn{2}{|c|}{ Mean dependent var } & 12.45401 \\
\hline Adjusted R-squared & 0.99632 & \multicolumn{2}{|c|}{ S.D. dependent var } & 0.365115 \\
\hline S.E. of regression & 0.022149 & \multicolumn{2}{|c|}{ Akaike info criterion } & -4.47698 \\
\hline
\end{tabular}




\begin{tabular}{|c|c|c|c|}
\hline Sum squared resid & 0.003925 & Schwarz criterion & -4.03587 \\
\hline Log likelihood & 47.05436 & F-statistic & 542.469 \\
\hline Durbin-Watson stat & 1.706707 & Prob(F-statistic) & 0 \\
\hline
\end{tabular}

Note: Robust standard errors in parentheses. ***Significant at 10\%; **significant at 5\%; *significant at $1 \%$.

The above results show that capital and exports have been very important to Vietnamese economic growth in the past two decades. Without reform and integration mentioned earlier, Vietnam couldn't have such impressive economic growth rate and success in reducing its poverty rate.

\section{CONCLUSIONS}

AND

RECOMMENDATIONS FOR FUTURE ECONOMIC DEVELOPMENT

Vietnam is in the process of world and regional economic integration. In the context of openness and integration, Vietnam is making major progress in economic development and improving the living standard of its population. As a full WTO member, Vietnam will have a lot of opportunities to expand its exports and attract foreign investment. From the above results of empirical models show that both these factors are expected to encourage economic growth. However, Vietnam also has some major challenges in improving investment environment, including:

(1) The process of restructuring SOEs goes slowly. This is to reduce a faith from investors

(2) The investment environment is not comprehensive (tax policy is complex, land policy is limited, and there is not an equal "playing field" for all kinds of enterprise).
(3) Administrative reform moves very slowly- this is also to limit investment.

To overcome these challenges, the Vietnamese government might consider several changes in its policies. Some possibilities are:

(1) Speed up the process of restructuring SOEs, encouraging and creating conditions for private sector to participate in producing, processing and trading industries. The state sector still dominates a lot of the productprocessing enterprises. Meanwhile SOEs are now facing more pressures in the process of competition and integration. To overcome these current constraints of SOEs, the Government should speed the process of restructuring and reorganizing the state sector through equalization, business contracts, or perfecting the general company model in order to create conditions for enterprises to have more active rights in business activities. Removing subsidy factors would be especially helpful in helping private enterprises and enhancing their competitiveness.

(2) Perfecting tax policy. In general, tax policy at present is complex and contains too many time-consuming procedures. Granting tax credits could considerably improve cash flows for businesses when high tax rates in the industry have greatly affected enterprise profit. To help enterprises in all processing and trading industries improve their

\section{Trang 20}


competitiveness, the government should simplify the tax code, applying the same fair tax rate to both SOEs and private ones in order to create an equal and explicit, sound competition business environment for all kinds of enterprise; and speed up the process of awarding tax credits.

(3) Modify land policies: Although many amendments have made to the legal system and land regulations, accessibility as well as the transfer of land-use rights is still limited. The registration and procedures involved in land transactions are still in the building process. This hampers private enterprises in expanding business sizes or changing location to a more convenient one.

(4) Improve investment opportunities, the business environment, and the "playing field" for all kinds of enterprise. According to the results of enterprise surveys, investment and business environment at the present is still unsound and risky due to unstable policies, unequal application of federal laws, and internal corruption. The government needs to create an equal "playing field" for enterprises in all economic sectors by rapidly setting up competition and anti-monopoly laws that apply to all economic sectors, control and prevent unsound competition behaviors like price control or market manipulations.

(5) Reform administrative procedures rapidly and thoroughly in all fields, particularly in the areas of customs and tax.
Simplifying procedures for investment licensing, loan borrowing, exporting and importing of goods, and land will increase incentives to improve production and business efficiency of all economic sectors

(6) Develop sustainable economic growth to benefit the poor. Economic indicators show that living standards are improving and that the poverty rates are decreasing in the reform period. However, the differential gap among alternate population groups is still high as measured by income or assets. There is also a differential gap in the poverty rates among the different provinces. This means that, although most of society has benefited from the county's economic growth, such disadvantaged groups as the landless, migrant workers, ethnic minority groups, elderly, women, and children have benefited less and the rich have benefited more. Regions with large ethnic minority groups also have high levels of poverty compared to other regions. To address this problem, the government should develop strategies for sustainable economic growth that will (1) benefit the poor, (2) further develop the country's economic infrastructure, (3) support job creation, and (4) develop non-farm employment opportunities in the rural areas of the country. 


\title{
PHÁT TRIỂN KINH TẾ NHỜ CẢI CÁCH VÀ HỘI NHậP VÀ NHŨ̂NG YẾU TỐ CHÍNH TÁC ĐỘNG ĐẾN TĂNG TRƯởNG KINH TẾ TẠI VIỆT NAM
}

\author{
Nguyễn Thị Cành, Trần Hùng Sơn \\ Trường Đại học Kinh tế Luật, ĐHQG-HCM
}

TÓM TÄT: Muc tiêu của bài nghiên cưu là giới thiệu một cách tổng quan về phát triển kinh tế Việt nam do cải cách và hội nhập kinh tế quốc tế mang lại và đánh giá nhũng nhân tố chính tác động đến tăng truởng kinh tế Việt nam trong giai đoạn đổi mói (1990-2009). Dựa vào số liệu thống kê về kinh tế Việt nam giai đoạn 1990-2009, nghiên cứu này đã phân tích các nhân tố tác động đến phát triển kinh tế Việt nam. Nhũng thay đổi về chính sách, phát triển kinh tế, tỷ lệ nghèo đói và mức sống dân cu Việt nam trong giai đoạn đổi mới được phân tích dự trên việc sử dụng các phuoong pháp phân tích định tính. Kết quả phân tích cho thấy tăng truởng kinh tế nhờ cải cách đổi mới chính sách kinh tế và hội nhập quốc tế đã có tác động làm giảm tỷ lệ nghèo đói và tăng mức sống dân cu tại Việt nam. Đánh giá các nhân tố tác động đến tăng truởng kinh tế, nghiên cứu đã sử dụng các mô hình định luợng gồm mô hình tổng năng suất nhân tố và mô hình kinh tế luợng khác. Nhũng khám phá tù phân tích định lương đã chỉ ra rằng đóng góp cho tăng truơong kinh tế Việt nam được xác định bởi hai yếu tố chính đó là (1) đầu tu vốn xã hội bao gồm cả đầu tu trục tiếp nuớc ngoài; (2) tăng truơong xuất khẩu. Kết quả phân tích định tính và phân tích định luợng là cơ sở đura ra các hàm ý và kiến nghị chính sách cho Chính phủ để phát triển kinh tế cho giai đoạn tóit.

\section{REFERENCES}

[1]. Charles R Hulten, Edwin R Dean and Michael J Harper, New Developments in Productivity Analysis, The University of Chicago Press, (2001).

[2]. David Romer, Advanced Macroeconomics, The MCGraw-Hill Companies, Inc, (1996).

[3]. Nguyen Thi Canh, Economic Growth Models: Theory and Application (in Vietnamese, Vietnam National University-Ho Chi Minh City Press, (2004).
[4]. Vietnam Government Statistic Office 1985-2008;

[5]. IMF, World Bank and UNDP Websites

[6]. Adeolu B. Ayanwale; FDI and economic growth : Evidence from Nigieria, AERC Research Paper 165, April 2007

[7]. Kevin H. Zhang; FDI and economic growth in China: A panel data study for 1992 - 2004, Working paper 2006.

[8]. Marta Bengoa Calvo; Foreign Direct Investment, Economic Freedom And Growth: New Evidence From LatinAmerica, Workshop on Economic

\section{Trang 22}


Freedom, held in Groningen in November (2001).

[9]. Edward M. Graham, Erika Wada; FDI in China: Effect on growth and economic performance, Oxford University Press (2001).

[10]. S.R.Keshava ; The effect of FDI on India and Chinese Economy; A comparative analysis, Working paper 2006.
[11]. N. Balamurali and C. Bogahawatte; Foreign Direct Investment and Economic Growth in Sri Lanka, Sri Lankan Journal of Agricultural Economics. Vol. 6, No. 1, (2004). 


\section{APPENDIX}

Appendix 1: GDP Growth and GDP per capita of Vietnam in the period 1990-2008

\begin{tabular}{|c|c|c|c|c|}
\hline Year & Population (Thousand Pers) & $\begin{array}{l}\text { GDP-Fixed price } \\
\text { (Billion VND) }\end{array}$ & GDP Growth (\%) & GDP per Capita (USD) \\
\hline 1985 & $60,096.0$ & 15,804 & 2.44 & 37 \\
\hline 1990 & $66,016.7$ & 131,968 & 5.10 & 105 \\
\hline 1991 & $67,242.4$ & 139,634 & 5.81 & 115 \\
\hline 1992 & $68,450.1$ & 151,782 & 8.70 & 158 \\
\hline 1993 & $69,644.5$ & 164,043 & 8.08 & 190 \\
\hline 1994 & $70,824.5$ & 178,534 & 8.83 & 229 \\
\hline 1995 & $71,995.5$ & 195,568 & 9.54 & 288 \\
\hline 1996 & $73,156.7$ & 213,832 & 9.34 & 333 \\
\hline 1997 & $74,306.9$ & 231,264 & 8.15 & 343 \\
\hline 1998 & $75,456.3$ & 244,596 & 5.76 & 344 \\
\hline 1999 & $76,596.7$ & 256,269 & 4.77 & 372 \\
\hline 2000 & $77,635.4$ & 273,666 & 6.79 & 391 \\
\hline 2001 & $78,685.8$ & 292,535 & 6.84 & 413 \\
\hline 2002 & $79,727.4$ & 313,247 & 7.20 & 440 \\
\hline 2003 & $80,902.4$ & 336,242 & 7.26 & 492 \\
\hline 2004 & $82,031.7$ & 362,435 & 7.70 & 552 \\
\hline 2005 & $83,106.3$ & 393,031 & 8.43 & 636 \\
\hline 2006 & $84,136.8$ & 425,135 & 8.17 & 723 \\
\hline 2007 & $85,154.9$ & 461,189 & 8.50 & 835 \\
\hline 2008 & $86,789.0$ & 490,530 & 6.23 & 1,047 \\
\hline 2009 & 85789,6 & 515909 & 5,32 & 1.109 \\
\hline $\begin{array}{c}\text { Average } \\
1990- \\
2009\end{array}$ & $1.53 \% /$ year & & $7.44 \% /$ year & \\
\hline
\end{tabular}

Source: Calculate from Vietnam Statistic Data- GSO and IMF Statistic Data

Appendix 2: GDP Growth by Sector

\begin{tabular}{|c|c|c|c|c|c|c|c|c|}
\hline \multirow[t]{2}{*}{ Year } & \multicolumn{2}{|c|}{ GDP } & \multicolumn{2}{|c|}{ Sector I } & \multicolumn{2}{|c|}{ Sector II } & \multicolumn{2}{|c|}{ Sector III } \\
\hline & Bill VND & $\%$ & Bill VND & $\%$ & Bill VND & $\%$ & Bill VND & $\%$ \\
\hline 1990 & 131968 & 5.09 & 42003 & 1.00 & 33221 & 2.27 & 56744 & 10.19 \\
\hline 1991 & 139634 & 5.81 & 42917 & 2.18 & 35783 & 7.71 & 60934 & 7.38 \\
\hline 1992 & 151782 & 8.70 & 45869 & 6.88 & 40359 & 12.79 & 65554 & 7.58 \\
\hline 1993 & 164043 & 8.08 & 47373 & 3.28 & 45454 & 12.62 & 71216 & 8.64 \\
\hline 1994 & 178534 & 8.83 & 48968 & 3.37 & 51540 & 13.39 & 78026 & 9.56 \\
\hline 1995 & 195567 & 9.54 & 51319 & 4.80 & 58550 & 13.60 & 85698 & 9.83 \\
\hline 1996 & 213833 & 9.34 & 53577 & 4.40 & 67016 & 14.46 & 93240 & 8.80 \\
\hline 1997 & 231264 & 8.15 & 55895 & 4.33 & 75474 & 12.62 & 99895 & 7.14 \\
\hline 1998 & 244596 & 5.76 & 57866 & 3.53 & 81764 & 8.33 & 104966 & 5.08 \\
\hline 1999 & 256272 & 4.77 & 60895 & 5.23 & 88047 & 7.68 & 107330 & 2.25 \\
\hline 2000 & 273666 & 6.79 & 63717 & 4.63 & 96913 & 10.07 & 113036 & 5.32 \\
\hline 2001 & 292535 & 6.89 & 65618 & 2.98 & 106986 & 10.39 & 119931 & 6.10 \\
\hline 2002 & 313247 & 7.08 & 68352 & 4.17 & 117125 & 9.48 & 127770 & 6.54 \\
\hline
\end{tabular}

Trang 24 


\begin{tabular}{|l|l|l|l|l|l|l|l|l|l|}
2003 & 336242 & 7.34 & 70827 & 3.62 & 129399 & 10.48 & 136016 & 6.45 \\
2004 & 362435 & 7.79 & 73917 & 4.36 & 142621 & 10.22 & 145897 & 7.26 \\
2005 & 393031 & 8.44 & 76888 & 4.02 & 157867 & 10.69 & 158276 \\
2006 & 425373 & 8.23 & 79722 & 3.69 & 174259 & 10.38 & 171392 \\
2007 & 461443 & 8.48 & 82436 & 3.40 & 192734 & 10.60 & 186273 \\
2008 & 490191 & 6,23 & 85560 & 3,79 & 204934 & 6.33 & 199685 \\
2009 & & & & & & & 7,2 \\
& 515909 & 5,32 & 87653 & 1,83 & 215047 & 5,52 & 213209 \\
\hline
\end{tabular}

Source: Vietnam GSO 1990-2008

Appendix 3: GDP, Capital and Labor by Sectors in the period 1990-2007

\begin{tabular}{|c|c|c|c|c|c|c|}
\hline \multirow[t]{2}{*}{ Year } & \multicolumn{3}{|c|}{ Capital (K)- } & \multirow[b]{2}{*}{ Log GDP } & \multirow[b]{2}{*}{$\log K$} & \multirow[b]{2}{*}{$\log L$} \\
\hline & GDP-Bill. VND & Bill. VND & Labor (L)-Person & & & \\
\hline \multicolumn{7}{|c|}{ All sectors } \\
\hline 1990 & 131968 & 22190.6 & 28412.3 & 5.1204686 & 4.34616905 & 4.453506 \\
\hline 1991 & 139634 & 26285.5 & 30134600 & 5.1449912 & 4.41971624 & 7.479065 \\
\hline 1992 & 151782 & 40189.1 & 31815000 & 5.1812203 & 4.60410828 & 7.502632 \\
\hline 1993 & 164043 & 54770 & 32718000 & 5.2149577 & 4.73854274 & 7.514787 \\
\hline 1994 & 178534 & 54296.3 & 33664000 & 5.2517209 & 4.73477024 & 7.527166 \\
\hline 1995 & 195568 & 64685 & 34590000 & 5.2912978 & 4.81080358 & 7.538951 \\
\hline 1996 & 213832 & 74315 & 35792000 & 5.3300727 & 4.87107648 & 7.553786 \\
\hline 1997 & 231264 & 88607 & 36994000 & 5.364108 & 4.94746803 & 7.568131 \\
\hline 1998 & 244596 & 90952 & 37867000 & 5.3884494 & 4.95881225 & 7.578261 \\
\hline 1999 & 256269 & 99855 & 36420000 & 5.4086961 & 4.99936982 & 7.56134 \\
\hline 2000 & 273666 & 115109 & 37609600 & 5.4372208 & 5.06110928 & 7.575299 \\
\hline 2001 & 292535 & 129460 & 38562700 & 5.4661778 & 5.1121356 & 7.586167 \\
\hline 2002 & 313247 & 147993 & 39507700 & 5.4958869 & 5.17024117 & 7.596682 \\
\hline 2003 & 336242 & 166814 & 40573800 & 5.526652 & 5.2222325 & 7.608246 \\
\hline 2004 & 362435 & 189319 & 41586300 & 5.5592301 & 5.2771942 & 7.61895 \\
\hline 2005 & 393031 & 213931 & 42542700 & 5.5944268 & 5.33027372 & 7.628825 \\
\hline 2006 & 425135 & 243306 & 43436100 & 5.6285269 & 5.38615282 & 7.637851 \\
\hline 2007 & 461189 & 306100 & 44171900 & 5.6638789 & 5.48586333 & 7.645146 \\
\hline \multicolumn{7}{|c|}{ Sector I } \\
\hline 1990 & 42003 & 3160.43 & 20740.3 & 4.6232803 & 3.49974618 & 4.316815 \\
\hline 1991 & 42917 & 4072.22 & 22167.2 & 4.6326294 & 3.60983123 & 4.345711 \\
\hline 1992 & 45869 & 4933.47 & 23272 & 4.6615193 & 3.69315249 & 4.366834 \\
\hline 1993 & 47373 & 10552.23 & 23556 & 4.6755309 & 4.02334425 & 4.372102 \\
\hline 1994 & 48968 & 7808.6 & 23820 & 4.6899124 & 3.89257318 & 4.376942 \\
\hline 1995 & 51319 & 11839.59 & 24122 & 4.7102782 & 4.07333666 & 4.382413 \\
\hline 1996 & 53577 & 12914.44 & 24775 & 4.7289784 & 4.11107558 & 4.394014 \\
\hline 1997 & 55895 & 15186.57 & 25443 & 4.747373 & 4.1814597 & 4.405568 \\
\hline 1998 & 57866 & 14369.35 & 26036 & 4.7624235 & 4.15743712 & 4.415574 \\
\hline 1999 & 60895 & 16679.7 & 25199 & 4.7845816 & 4.22218824 & 4.401383 \\
\hline 2000 & 63717 & 16354.63 & 24481 & 4.8042553 & 4.21364072 & 4.388829 \\
\hline
\end{tabular}




\begin{tabular}{|c|c|c|c|c|c|c|}
\hline 2001 & 65618 & 12256.85 & 24468.4 & 4.817023 & 4.08837887 & 4.388606 \\
\hline 2002 & 68352 & 12968.84 & 24455.8 & 4.8347512 & 4.11290113 & 4.388382 \\
\hline 2003 & 70827 & 14166.7 & 24443.4 & 4.8501988 & 4.1512687 & 4.388162 \\
\hline 2004 & 73917 & 15012.75 & 24430.7 & 4.8687443 & 4.17646025 & 4.387936 \\
\hline 2005 & 76888 & 16123.3 & 24351.5 & 4.8858586 & 4.20745393 & 4.386526 \\
\hline 2006 & 79722 & 18087.79 & 24172.3 & 4.9015782 & 4.25738551 & 4.383318 \\
\hline 2007 & 82436 & 19890.34 & 24103.9 & 4.9161169 & 4.29864221 & 4.382087 \\
\hline \multicolumn{7}{|c|}{ Sector II } \\
\hline 1990 & 33221 & 5217.33 & 3041.5 & 4.5214127 & 3.71744831 & 3.483088 \\
\hline 1991 & 35783 & 7303.41 & 3130.4 & 4.5536767 & 3.86352568 & 3.4956 \\
\hline 1992 & 40359 & 11001.78 & 3915 & 4.6059404 & 4.04146296 & 3.592732 \\
\hline 1993 & 45454 & 20297.25 & 4045 & 4.6575721 & 4.3074372 & 3.606919 \\
\hline 1994 & 51540 & 20486.7 & 4319 & 4.7121444 & 4.31147201 & 3.635383 \\
\hline 1995 & 58550 & 18784.96 & 4582 & 4.7675269 & 4.27381027 & 3.661055 \\
\hline 1996 & 67016 & 23520.95 & 4629 & 4.8261785 & 4.37145486 & 3.665487 \\
\hline 1997 & 75474 & 31015.23 & 4633 & 4.8777974 & 4.49157501 & 3.665862 \\
\hline 1998 & 81764 & 34802.45 & 4675 & 4.9125621 & 4.54160982 & 3.669782 \\
\hline 1999 & 88047 & 37280.05 & 4239 & 4.9447146 & 4.57147649 & 3.627263 \\
\hline 2000 & 96913 & 46334.86 & 4929.7 & 4.986382 & 4.66590786 & 3.69282 \\
\hline 2001 & 106986 & 54859.68 & 5551.9 & 5.029327 & 4.73925327 & 3.744442 \\
\hline 2002 & 117125 & 62654.77 & 6084.7 & 5.0686496 & 4.79695414 & 3.784239 \\
\hline 2003 & 129399 & 69217.88 & 6670.5 & 5.1119309 & 4.84021829 & 3.824158 \\
\hline 2004 & 142621 & 81311.93 & 7216.5 & 5.1541835 & 4.91015427 & 3.858327 \\
\hline 2005 & 157867 & 91486.22 & 7785.3 & 5.1982914 & 4.96135568 & 3.891275 \\
\hline 2006 & 174259 & 102763.2 & 8296.9 & 5.2411952 & 5.01183762 & 3.918916 \\
\hline 2007 & 192734 & 133134.4 & 8638.3 & 5.2849583 & 5.12429029 & 3.936428 \\
\hline \multicolumn{7}{|c|}{ Sector III } \\
\hline 1990 & 56744 & 13812.87 & 4630.5 & 4.7539199 & 4.14028392 & 3.665628 \\
\hline 1991 & 60934 & 14909.86 & 4837 & 4.7848597 & 4.17347357 & 3.684576 \\
\hline 1992 & 65554 & 24253.88 & 4628 & 4.8165992 & 4.38478122 & 3.665393 \\
\hline 1993 & 71216 & 23920.58 & 5117 & 4.8525776 & 4.37877171 & 3.709015 \\
\hline 1994 & 78026 & 26001 & 5525 & 4.8922393 & 4.41499005 & 3.742332 \\
\hline 1995 & 85698 & 34060.45 & 5886 & 4.9329707 & 4.53225038 & 3.76982 \\
\hline 1996 & 93240 & 37879.61 & 6388 & 4.9696023 & 4.5784055 & 3.805365 \\
\hline 1997 & 99895 & 42405.2 & 6918 & 4.9995438 & 4.62741912 & 3.839981 \\
\hline 1998 & 104966 & 41780.2 & 7156 & 5.0210486 & 4.62097051 & 3.85467 \\
\hline 1999 & 107330 & 45895.24 & 6982 & 5.0307211 & 4.66176765 & 3.84398 \\
\hline 2000 & 113036 & 55427.45 & 8198.9 & 5.0532168 & 4.7437249 & 3.913756 \\
\hline 2001 & 119931 & 62343.48 & 8542.4 & 5.0789315 & 4.79479104 & 3.93158 \\
\hline 2002 & 127770 & 72369.39 & 8967.2 & 5.1064289 & 4.85955491 & 3.952657 \\
\hline 2003 & 136016 & 83429.42 & 9459.9 & 5.13359 & 4.92131922 & 3.975887 \\
\hline 2004 & 145897 & 92994.32 & 9939.1 & 5.1640464 & 4.96845642 & 3.997347 \\
\hline 2005 & 158276 & 106321.5 & 10405.9 & 5.1994151 & 5.0266211 & 4.01728 \\
\hline
\end{tabular}

Trang 26 
TẠP CHI PHÁT TRIỂN KH\&CN, TậP 14, SỐ Q1 - 2011

\begin{tabular}{|c|c|c|c|c|c|c|}
\hline 2006 & 171392 & 122455 & 10966.9 & 5.2339905 & 5.08797652 & 4.040084 \\
\hline 2007 & 186273 & 153075.2 & 11429.7 & 5.2701499 & 5.18490484 & 4.058035 \\
\hline
\end{tabular}

Source: Vietnam GSO 1990-2008

\begin{tabular}{|l|l|l|l|l|}
\multicolumn{2}{|c|}{ Appendix 4: Model Summary } \\
\hline \multirow{2}{*}{ Model } & R & R Square & Adjusted R Square & $\begin{array}{l}\text { Std. Error of the } \\
\text { Estimate }\end{array}$ \\
\hline 1 & $.980(a)$ & .960 & .959 & .05827 \\
\hline
\end{tabular}

ANOVA(b)

\begin{tabular}{|c|c|c|c|c|c|c|}
\hline Model & & Sum of Squares & $\mathrm{df}$ & Mean Square & $\mathrm{F}$ & Sig. \\
\hline 1 & $\begin{array}{c}\text { Regression } \\
\text { Residual } \\
\text { Total }\end{array}$ & $\begin{array}{l}5.594 \\
.234 \\
5.828\end{array}$ & $\begin{array}{l}2 \\
69 \\
71\end{array}$ & $\begin{array}{c}2.797 \\
.003\end{array}$ & 823.746 & $.000(\mathrm{a})$ \\
\hline
\end{tabular}

\begin{tabular}{|c|c|c|c|c|c|c|}
\hline \multicolumn{2}{|c|}{ Model } & \multicolumn{2}{|c|}{ Unstandardized Coefficients } & \multirow{2}{*}{$\frac{\text { Standardized Coefficients }}{\text { Beta }}$} & \multirow{2}{*}{$\frac{\mathrm{t}}{\mathrm{B}}$} & \multirow{2}{*}{$\frac{\text { Sig. }}{\text { Std. Error }}$} \\
\hline & & B & Std. Error & & & \\
\hline \multirow[t]{3}{*}{1} & (Constant) & 1.566 & .094 & & 16.585 & .000 \\
\hline & $\log K$ & .546 & .015 & .870 & 35.223 & .000 \\
\hline & $\log \mathrm{L}$ & .235 & .019 & .304 & 12.330 & .000 \\
\hline
\end{tabular}

a Dependent Variable: LogGDP 